\title{
Het belang van een degelijk colostrummanagement op moderne rundveebedrijven
}

\author{
V. Meganck, J. Laureyns, G. Opsomer \\ Vakgroep Voortplanting, Verloskunde en Bedrijfsdiergeneeskunde \\ Faculteit Diergeneeskunde, Universiteit Gent, Salisburylaan 133, 9820 Merelbeke, België \\ Vanessa.Meganck@UGent.be
}

\begin{abstract}
SAMENVATTING
Het pasgeboren kalf is afhankelijk van de absorptie van colostrale immunoglobulinen of antistoffen. Een goed colostrummanagement is een van de belangrijkste preventieve maatregelen tegen infectieuze ziekten bij jonge kalveren. Toch worden hier nog veel fouten tegen gemaakt of bestaan er nog veel misvattingen. Bovendien is ook meer en meer bewijs voorhanden dat colostrum niet alleen van levensbelang is voor de aanvoer van antistoffen maar evenzeer voor de aanvoer van andere substanties, zoals groeifactoren en immuuncellen.
\end{abstract}

\section{INLEIDING}

Een kalf wordt agammaglobulinemisch geboren door de specifieke bouw van de runderplacenta (Arthur, 1996). Dit maakt het kalf afhankelijk van de absorptie van colostrale immunoglobulinen (Igs) of antistoffen na de geboorte (Klaus et al., 1969; Haines et al., 2011). Dit belangrijke proces wordt aangeduid met de term passieve immuniteit. Er zijn meerdere voorbeelden te vinden in de literatuur die aantonen dat kalveren die er niet in slagen om voldoende antistoffen op te nemen, een verhoogd risico hebben op morbiditeit en mortaliteit (Robison et al., 1988; Tyler et al., 1998; Tyler et al., 1999c; Waldner et al., 2009). Bovendien is ook al meermaals bewezen dat een onvoldoende biestopname samengaat met een vertraagde groei en latere productiederving (Robison et al., 1988; Furman-Fratczak et al., 2011). Een te lage opname van colostrale antistoffen wordt aangeduid met de term 'failure of passive transfer (FPT)'. Het kalf slaagt er niet in om voldoende passieve immuniteit te verwerven. Een kalf moet vanaf twee dagen na de geboorte minstens $10 \mathrm{mg} / \mathrm{ml} \mathrm{immu-}$ noglobuline $\mathrm{G}(\mathrm{IgG})$ in het serum hebben (Besser et al., 1991; Tyler et al., 1996; Calloway et al., 2002; Dawes et al., 2002; Godden, 2008; Beam et al., 2009). Deze grens wordt echter door meerdere auteurs betwist als zijnde waarschijnlijk te laag (Chigerwe et al., 2008; Tyler et al., 1998). Of een kalf deze grens van $10 \mathrm{mg} / \mathrm{ml}$ $\mathrm{IgG}$ in het serum al dan niet bereikt, hangt af van drie belangrijke factoren. Ten eerste moet er voldoende colostrum van goede kwaliteit beschikbaar zijn. Over het algemeen wordt aangenomen dat per liter biest minstens $50 \mathrm{~g} \mathrm{IgG} \mathrm{moet} \mathrm{aanwezig} \mathrm{zijn} \mathrm{(Fleenor} \mathrm{et} \mathrm{al.,}$ 1980; Pritchett et al., 1994; Chigerwe et al., 2008). Ten tweede moet het kalf voldoende van dit colostrum opnemen en ten derde moet het kalf de opgenomen antistoffen via het gastro-intestinaal stelsel op een efficiënte manier absorberen in het bloed. Een groot aantal factoren kan echter invloed hebben op één of meerdere van de hierboven genoemde vereisten. De rundveehouder zelf speelt hierin een beslissende rol.

\section{COLOSTROGENESIS}

Colostrogenesis is het proces waarbij prepartum Igs worden overgedragen van de maternale circulatie naar de uier. Dit proces komt bij runderen reeds verscheidene weken vóór de partus op gang, stopt abrupt op het moment van de partus en is onderhevig aan een bepaalde combinatie van (lactogene) hormonen (oestrogenen, progesteron, prolactine, corticosteroïden, groeihormonen) (Godden et al., 2008). De belangrijkste Igs die overgaan van het bloed naar de uier zijn IgG1 en IgG2. Dit gebeurt via een specifiek receptorgemedieerd proces (Kemler et al., 1975). In mindere mate gaat het om IgM en IgA. Deze laatste twee worden voornamelijk lokaal, ter hoogte van het uierparenchym geproduceerd. In de literatuur worden verschillende definities van colostrum gebruikt, gaande van de eerste melkbeurt postpartum tot de melkbeurten gedurende de eerste twee dagen postpartum (Archambault et al., 1988; Ohtsuka et al., 2011). Aangezien na de eerste melkbeurt het antistoffengehalte sterk daalt en gezien antistoffen onontbeerlijk zijn voor het pasgeboren kalf, willen de auteurs stellen dat de benaming colostrum dient weerhouden te worden voor de allereerste melkbeurt na kalving.

\section{SAMENSTELLING VAN HET COLOSTRUM}

Colostrum is een belangrijke bron van voedingsstoffen voor het kalf. Biest bevat in vergelijking met 'gewone' melk een hoger gehalte aan eiwitten, vetten, mineralen en vitaminen. Aangezien eiwitten, vetten en suikers bijdragen tot het proces van thermogenese, is colostrum belangrijk voor een normale thermoregulatie van het pasgeboren kalf (Vermorel et al., 1983). Het laxatieve effect van colostrum zorgt dan weer voor een vlot afkomen van de eerste mest of het meconium (Kuralkar en Kuralkar, 2010). Colostrum is daarnaast vooral bekend omwille van zijn hoog gehalte aan Igs en het belang daarvan voor het afweersysteem van het kalf. Van alle Igs vormt IgG het hoofdaandeel, namelijk 85-90\% (Butler, 1974). Immunoglobuline $\mathrm{M}$ en 
IgA vormen respectievelijk 7\% en 5\% van de Igs (Levieux en Ollier, 1999). Voor de opbouw van de immuniteit van het kalf winnen naast antistoffen ook colostrale leukocyten meer en meer aan belang. Hierop wordt later meer uitgebreid ingegaan. Colostrum bevat nog vele andere componenten in een hogere concentratie dan melk. Deze zijn samengevat in Tabel 1.

\section{DE KWALITEIT VAN HET COLOSTRUM}

\section{Antistofinhoud}

Zoals hoger vermeld wordt algemeen aanvaard dat colostrum minstens $50 \mathrm{~g}$ IgG per liter moet bevatten (Fleenor et al., 1980; Pritchett et al., 1994; Chigerwe et al., 2008). Als aan deze minimumnorm voldaan wordt, kan er gesproken worden van biest van goede

Tabel 1. Gemiddelde samenstelling van colostrum en 'gewone' melk bij holsteinkoeien (naar Foley en Otterby, 1978, Kehoe et al., 2007, Georgiev, 2008 en Godden, 2008).

\begin{tabular}{|c|c|c|}
\hline Parameter & $\begin{array}{c}\text { Melkbeurt 1 } \\
= \\
\text { Colostrum }\end{array}$ & $\begin{array}{c}\text { Melkbeurt } 6 \\
= \\
\text { ('gewone' melk) }\end{array}$ \\
\hline Dichtheid & 1,056 & 1,032 \\
\hline Vaste stof (\%) & $23,9-27,64$ & 12,9 \\
\hline Vet $(\%)$ & 6,7 & 4,0 \\
\hline Totaal eiwit (\%) & $14,0-14,92$ & 3,1 \\
\hline Caseïne (\%) & 4,8 & 2,5 \\
\hline Albumine (\%) & 6,0 & 0,5 \\
\hline Immunoglobulinen (\%) & 6,0 & 0,09 \\
\hline $\operatorname{IgG}(\mathrm{g} / 100 \mathrm{ml})$ & 3,2 & 0,06 \\
\hline IgG1 (mg/ml) & 34,96 & - \\
\hline IgG2 (mg/ml) & 6,00 & - \\
\hline $\operatorname{IgA}(\mathrm{mg} / \mathrm{ml})$ & 1,66 & - \\
\hline IgM (mg/ml) & 4,32 & - \\
\hline Lactose (\%) & $2,49-2,7$ & 5,0 \\
\hline Lactoferrine (mg/ml) & 0,82 & - \\
\hline IGF-I $(\mu \mathrm{g} / \mathrm{l})$ & 341 & 15 \\
\hline Insuline $(\mu \mathrm{g} / \mathrm{l})$ & $4,2-65,9$ & $0,042-1,1$ \\
\hline Totaal cortisol (ng/ml) & 4,4 & 0,35 \\
\hline Prolactine (ng/ml) & 150 & 50 \\
\hline Progesteron (ng/ml) & & $2,6 \quad 0,8$ \\
\hline Plasmine $(\mu \mathrm{g} / \mathrm{ml})$ & 0,49 & 0,04 \\
\hline$\alpha 1$-antitrypsine $(\mu \mathrm{g} / \mathrm{ml})$ & $250-800$ & $6-20$ \\
\hline As (\%) & 1,11 & 0,74 \\
\hline Calcium (\%) & 0,26 & 0,13 \\
\hline Magnesium (\%) & 0,04 & 0,01 \\
\hline Fosfor (mg/kg) & $4.452,10$ & - \\
\hline Natrium (mg/kg) & 1058,93 & - \\
\hline Kalium (mg/kg) & $2.845,89$ & - \\
\hline Koper (mg/kg) & 0,34 & - \\
\hline Zwavel (mg/kg) & $2.595,67$ & - \\
\hline Zink (mg/100 ml) & $1,22-3,81$ & 0,3 \\
\hline Mangaan (mg/100 ml) & $0,01-0,02$ & 0,004 \\
\hline Ijzer (mg/100 g) & $0,20-0,53$ & 0,05 \\
\hline Kobalt $(\boldsymbol{\mu g} / \mathbf{1 0 0 g})$ & 0,5 & 0,10 \\
\hline Vitamine $A(\mu \mathrm{g} / 100 \mathrm{ml})$ & 295 & 34 \\
\hline Vitamine $E$ ( $\mu \mathrm{g} / \mathrm{g}$ vet) & $77,17-84$ & 15 \\
\hline Riboflavine $(\mu \mathrm{g} / \mathrm{ml})$ & $4,55-4,83$ & 1,47 \\
\hline Vitamine $\mathrm{B} 12(\mu \mathrm{g} / 100 \mathrm{ml})$ & 4,9 & 0,6 \\
\hline Thiamine ( $\mu \mathrm{g} / \mathrm{ml})$ & $0,58-0,90$ & 0,38 \\
\hline Foliumzuur $(\mu \mathrm{g} / 100 \mathrm{ml})$ & 0,8 & 0,2 \\
\hline Choline (mg/ml) & 0,7 & 0,13 \\
\hline Ascorbinezuur (mg/100ml) & 2,5 & 2,2 \\
\hline
\end{tabular}


kwaliteit. De antistofinhoud van colostrum varieert echter enorm van koe tot koe met metingen van $<10$ tot 235 g IgG per liter (Kehoe et al., 2007; Chigerwe et al., 2008; Gulliksen et al., 2008; Baumrucker et al., 2010; Morin et al., 2010; Herr et al., 2011). In een door ons uitgevoerde steekproef bij 353 holsteinkoeien in Vlaanderen en Nederland werd een spreiding van 0 tot 215 g IgG per liter biest waargenomen. Opmerkelijk was dat de minimumgrens van $50 \mathrm{~g}$ IgG per liter slechts in $12 \%$ van de biestmonsters niet werd bereikt. De cijfers in de literatuur geven een hoger percentage aan, namelijk 32-58\% (Chigerwe et al., 2008; Gulliksen et al., 2008). Aangezien er discussie is over de minimumgrens van $10 \mathrm{~g}$ IgG per liter serum voor jonge kalveren, is de algemeen aangenomen minimumgrens van 50 g IgG per liter biest mogelijk ook te laag. Hier wordt verder in het artikel dieper op ingegaan. Uiteraard moet ook rekening gehouden worden met het feit dat al deze studies bij verschillende holsteinpopulaties (verschillende genetische samenstelling) zijn gebeurd. Bovendien is de definitie van colostrum soms onduidelijk en wordt niet altijd dezelfde meettechniek toegepast.

\section{Bacteriologische kwaliteit}

Bacteriën in de biest vormen een tweevoudig probleem. Enerzijds zijn ze een bedreiging voor de gezondheid van het kalf en anderzijds zorgen ze voor een verminderde beschikbaarheid van de colostrale Igs.

Streefwaarden voor de bacteriologische kwaliteit van biest zijn: $<100.000 \mathrm{CFU}$ (colony forming units $) / \mathrm{ml}$ voor het algemene kiemgetal en $<10.000$ $\mathrm{CFU} / \mathrm{ml}$ voor de telling van de coliformen (McGuirk en Collins, 2004). Sommigen adviseren om de biest te pasteuriseren en zo een goede bacteriologische kwaliteit te garanderen. Dit zou het risico op overdracht van ziekten, zoals paratuberculose, sterk reduceren (Stabel et al., 2004). Het grootste probleem daarbij is echter dat de nodige apparatuur vrij ingewikkeld en duur is, aangezien het heel belangrijk is om de biest gedurende 60 minuten op precies $60^{\circ} \mathrm{C}$ te verwarmen. Indien deze temperatuur wordt overschreden, worden de Igs afgebroken en krijgt de biest door het stijgen van de viscositeit een yoghurtachtige structuur, waardoor ze niet meer drinkbaar is (McMartin et al., 2006). De belangrijkste basisregels voor het verstrekken van biest van een goede bacteriologische kwaliteit zijn het hygiënisch uitmelken van de biest, het hygiënisch en koel bewaren en het hygiënisch verstrekken van de biest.

\section{Meten van de colostrumkwaliteit (antistoffen)}

De colostrumkwaliteit kan op verschillende manieren gemeten worden. De belangrijkste zijn: direct via het gebruik van radiale immunodiffusie (RID) of "enzyme linked immunosorbent assay" (ELISA) en indirect via het gebruik van een hydrometer of een refractometer. De directe methoden zijn het meest precies maar vereisen een laboratorium en getraind personeel. De meest praktische manier is het gebruik van de hydrometer (colostrometer genaamd). Dit is een zogenaamde "cow side test" die gemakkelijk en snel door de rundveehouder zelf kan uitgevoerd worden en die bovendien ook goedkoop is. Op basis hiervan kan vervolgens beslist worden of de verse biest kan toegediend worden aan het kalf (wat de voorkeur geniet) of dat men moet overschakelen op een dosis diepvriesbiest van goede kwaliteit (hetgeen de voorkeur geniet boven verse biest van slechte kwaliteit). De colostrometer meet de densiteit van de biest, die gerelateerd is aan de IgG-inhoud. De biest wordt in een cilinder gegoten, waarna men de colostrometer voorzichtig in de biest laat drijven. Op basis van een kleurcodering op de colostrometer (donkergroen, lichtgroen of geel en rood) kan eenvoudig afgelezen worden of de biest al dan niet van goede kwaliteit is. Ook de densiteit kan met dit toestel gemeten worden en kan via een schaal geconverteerd worden naar g IgG/l biest. Donkergroen komt overeen met goede kwaliteitsbiest (minstens $50 \mathrm{~g} \mathrm{IgG/1),} \mathrm{lichtgroen}$ of geel met middelmatige kwaliteitsbiest (tussen 20 en $50 \mathrm{~g} \mathrm{IgG/1)} \mathrm{en} \mathrm{rood} \mathrm{met} \mathrm{slechte} \mathrm{kwaliteitsbiest} \mathrm{(minder}$ dan $20 \mathrm{~g} \mathrm{IgG/1).} \mathrm{Uiteraard} \mathrm{zijn} \mathrm{er} \mathrm{wel} \mathrm{nadelen} \mathrm{verbon-}$ den aan het gebruik van de colostrometer. Niet enkel Igs beïnvloeden de densiteit van de biest. Er is dus altijd variatie in de accuraatheid van deze methode. De waarde $\mathrm{R}^{2}$ wordt gebruikt om te beschrijven hoeveel van de variatie verklaard wordt door een bepaald model. Deze waarde gaat van 0 tot 1 , waarbij 1 betekent dat alle variatie kan verklaard worden door het gebruikte model. De $\mathrm{R}^{2}$, die gebruikt wordt om de relatie tussen de densiteit en de IgG-concentratie te beschrijven, varieert van 0,3 tot 0,4 . Bovendien speelt de temperatuur van de biest een belangrijke rol. Hoe kouder de biest, hoe meer de kwaliteit van de biest overschat wordt en hoe warmer de biest, hoe meer de colostrumkwaliteit onderschat wordt (Mechor et al., 1992). De ideale biesttemperatuur waarbij de kwaliteit met behulp van de colostrometer bepaald wordt, is $20^{\circ} \mathrm{C}$. Dit wil echter niet zeggen dat de biest aan kamertemperatuur moet bewaard worden. Dit laatste zou immers een explosieve groei van de aanwezige bacteriën veroorzaken met een slechte bacteriologische kwaliteit als gevolg. De sensitiviteit van de colostrometer wordt geschat op 0,32-0,47, de specificiteit op 0,930,97 (Pritchett et al., 1994; Chigerwe et al., 2008). Dit wil zeggen dat als de colostrometer aangeeft dat het om goede kwaliteitsbiest (eenheid $1050=$ minstens $50 \mathrm{~g}$ $\mathrm{IgG} / 1)$ gaat, dit in ongeveer $95 \%$ van de gevallen ook effectief zo is. Echter, door de lage sensitiviteit van de colostrometer is de kans vrij groot dat biest wordt weggegooid die wel van goede kwaliteit is. Nog een laatste klein nadeel is dat de hydrometer van glas gemaakt is en dus breekbaar is.

Ook de refractometer is een eenvoudig en vrij goedkoop hulpmiddel dat door de rundveehouder zelf kan gebruikt worden om de biestkwaliteit te bepalen. De refractometer meet hoeveel het licht afgebogen wordt, hetgeen overeenkomt met het gehalte vaste stoffen in 
de biest. Aangezien eiwitten $64 \%$ van de vaste stoffen in het colostrum uitmaken en antistoffen $47 \%$ van de eiwitten uitmaken, bestaat er een verband tussen de refractie-index en de IgG-inhoud van de biest (Fleenor et al., 1980; Moore et al., 2009). De voordelen van de refractometer tegenover de colostrometer zijn dat hij temperatuursonafhankelijk werkt (Bielmann et al., $2010)$ en een hogere sensitiviteit $(0,75-0,93)$ heeft. De specificiteit is echter iets lager $(0,78-0,85)$ (Chigerwe et al., 2008; Bielmann et al., 2010).

\section{FACTOREN DIE DE COLOSTRUMKWALITEIT BEÏNVLOEDEN (ANTISTOFFEN)}

Er zijn veel factoren die een invloed uitoefenen op de concentratie van antistoffen in de biest. Hieronder worden de belangrijkste besproken. Deze lijst is echter zeker niet volledig.

\section{Het tijdstip van uitmelken}

Teneinde biest te verzamelen van een zo hoog mogelijke kwaliteit, is het enorm belangrijk om de koe zo snel mogelijk na de partus uit te melken. Hoe langer men wacht met het uitmelken van de biest, hoe lager de antistofinhoud van de biest wordt. Moore et al. (2005) toonden aan dat de antistofinhoud van de biest gemiddeld $113 \mathrm{~g} / 1,94 \mathrm{~g} / 1,82 \mathrm{~g} / 1$ en $76 \mathrm{~g} / 1$ is bij het uitmelken van de koe op respectievelijk 2, 6, 10 en 14 uur na de partus. Dit komt omdat het uierweefsel in die periode extra melk produceert, waardoor de biest verdund wordt. Het is eveneens mogelijk dat er vanuit de biest een resorptie van IgGs naar de maternale circulatie gebeurt (Moore et al., 2005).

\section{Het ras}

De gemiddelde antistofinhoud van de biest verschilt tussen verschillende koeienrassen. Het verschil tussen melkkoeien en vleeskoeien is algemeen bekend, maar ook tussen melkveerassen onderling is er een groot verschil. Ayrshire-, brown swiss-, guernsey-, holstein-, Noors rood- en jerseykoeien hebben een gemiddelde antistofinhoud van respectievelijk $80,8 \mathrm{~g} / \mathrm{l}$, $65,7 \mathrm{~g} / 1,63,1 \mathrm{~g} / 1,48,2-55,9 \mathrm{~g} / 1,51,7$ en $65,8-90,4 \mathrm{~g} / 1$ (Muller et al., 1981; Morin et al., 2001; Gulliksen et al., 2008; Tyler et al., 1999a; Pritchett et al., 1991; Quigley et al., 1994).

\section{Het productieniveau}

Natuurlijk speelt ook het individueel productieniveau een grote rol. Hoe meer melk een koe gemiddeld produceert, hoe lager de antistofinhoud van de biest gemiddeld is. Dit is te wijten aan het verdunningseffect. Een studie van Pritchett et al. (1991) becijferde dat holsteinkoeien die minder dan $8,5 \mathrm{~kg}$ melk produceren, meer kans hebben om goede kwaliteitsbiest (> $50 \mathrm{~g} \mathrm{IgG/1)} \mathrm{te}$ geven dan koeien die meer dan $8,5 \mathrm{~kg}$ biest produceren. Als algemene vuistregel kan men stellen dat hoe meer biest de koe produceert, hoe lager de antistofinhoud is.

\section{De pariteit}

Een ander bekend gegeven is dat, hoe ouder de koe is, hoe groter de kans is dat ze biest van goede kwaliteit produceert (Kruse, 1970). Het is echter achterhaald dat biest afkomstig van vaarzen van een onvoldoende kwaliteit zou zijn en dus standaard zou moeten vermeden worden om aan pasgeboren kalveren te geven. Verschillende studies tonen aan dat ook een groot deel van de vaarzen biest produceert die voldoet aan de minimumgrens van $50 \mathrm{~g} \mathrm{IgG} \mathrm{per} \mathrm{liter} \mathrm{(Baumrucker} \mathrm{et}$ al., 2010; Chigerwe et al., 2008). De onderliggende oorzaak van het ondertussen bekende fenomeen dat oudere koeien biest van een hogere kwaliteit produceren, is dat zij vaker in contact zijn geweest met ziektekiemen en derhalve meer antistoffen hebben aangemaakt die rond het moment van het afkalven getransfereerd worden naar de uier en vervolgens in de biest terechtkomen.

\section{De voeding van de droogstaande koe}

Een veel gehoorde misvatting is dat de voeding van de droogstaande koe een grote invloed zou hebben op de colostrumkwaliteit. Meerdere studies hebben aangetoond dat diëten met een laag eiwitgehalte prepartum geen invloed hebben op de IgG-inhoud van de daaropvolgende geproduceerde biest (Quigley en Drewry, 1998). In verschillende studies is er ook nagegaan wat het effect is van verschillende hoeveelheden ruw eiwit (RE) of metaboliseerbare (ME) energie. Vrijwel altijd kon men opmaken dat enkel een ernstige onder- of overvoeding een relatief klein effect heeft (Halliday et al., 1978; Blecha et al., 1981; Hough et al., 1990). Over de invloed van de toevoeging van selenium aan het dieet van de droogstaande koe op de colostrumkwaliteit lopen de meningen uiteen. Lacetera et al. (1996) zagen geen verschil tussen de colostrumkwaliteit van koeien die een dieet met selenium werden toegediend en dieren waarvan het dieet geen selenium bevatte. Ze stelden echter wel een groter colostrumvolume vast bij de dieren die het seleniumdieet kregen. Pavlata et al. (2004) zagen dan weer wel een betere colostrumkwaliteit bij de met het seleniumdieet gevoederde dieren. Ook over de kation-anionbalans (DCAB, "dietary cation-anion balance") in het voeder en de invloed daarvan op de biestkwaliteit wordt veel gediscussieerd. Delaquis en Block (1995) vonden dat de productie van eiwit en lactose in de melk significant hoger lag bij een hogere DCAB. Dit was echter volledig te wijten aan een verhoogde melkproductie. Ook Tucker et al. (1991) vonden dat het percentage melkvet, de melkproductie zelf en de productie van eiwit in de melk het hoogst waren bij koeien die de hogere DCAB gevoederd werden. Echter, het eiwitpercentage verschilde niet met dat van de koeien die de lagere DCAB werden gevoederd.

\section{De lengte van de droogstand}

In het merendeel van de studies omtrent de invloed van de lengte van de droogstand op de kwaliteit van 
biest kon worden aangetoond dat enkel een extreem korte droogstand ( geen of slechts enkele dagen) een invloed heeft op de hoeveelheid antistoffen aanwezig in de biest. Rastini et al. (2005) konden geen verschil in colostrumkwaliteit aantonen tussen holsteinkoeien die ofwel 28 dagen ofwel 56 dagen droog hadden gestaan. Besser et al. toonden in 1991 aan dat koeien zonder droogstand gemiddeld maar de helft van de biestkwaliteit (gemeten op basis van de antistofinhoud) haalden in vergelijking met koeien die 28 dagen hadden droog gestaan.

\section{Mastitis}

De meeste studies tonen een negatieve invloed van mastitis aan op de colostrumkwaliteit (Maunsell et al., 1998; Leitner et al., 2008). Uiteraard is het geven van biest afkomstig van een klinisch aangetast kwartier te vermijden.

\section{Het seizoen en/of omgevingstemperatuur}

Vaarzen blootgesteld aan hittestress produceren biest van een lagere kwaliteit (Nardone et al., 1997). In de literatuur is er echter geen eensgezindheid omtrent de vraag of het seizoen van het afkalven al dan niet een effect heeft op de kwaliteit van biest. Sommige studies tonen aan dat de IgG-waarden in de biest van koeien die gedurende de wintermaanden afkalven significant lager liggen (Gulliksen et al., 2007). In andere studies kunnen dan weer geen (significante) verschillen gevonden worden.

\section{DE OPNAME VAN COLOSTRUM DOOR HET KALF}

\section{Hoeveel IgG is genoeg?}

De vanouds aangenomen minimumhoeveelheid van $100 \mathrm{~g} \mathrm{IgG}$ die moet opgenomen worden door het kalf om de minimumgrens van $10 \mathrm{~g} \mathrm{IgG}$ per liter serum te bekomen, wordt betwist door onder andere Chigerwe et al. (2008). Zij berekenden dat er minstens 153 g IgG moet opgenomen worden door het kalf en dat de grens van $10 \mathrm{~g} \mathrm{IgG/1} \mathrm{serum} \mathrm{moet} \mathrm{verhoogd} \mathrm{worden} \mathrm{naar} 13,4$ $\mathrm{g}$ IgG per liter. De auteurs van het voorliggend artikel stellen met enige voorzichtigheid dat meer onderzoek nodig is en dat de werkelijke minimumgrens waarschijnlijk nog hoger ligt. Recent voerden de auteurs een veldonderzoek uit in Vlaanderen en Nederland. Bij het testen van kalveren op probleembedrijven inzake neonatale diarree en zonder goed biestmanagement werd vastgesteld dat slechts 10 respectievelijk 19\% van de kalveren kon ingedeeld worden als FPT-kalveren waarbij de grens van 10 respectievelijk $15 \mathrm{~g}$ IgG per liter gesteld werd. De gemiddelde hoeveelheid serum IgG was $22,34 \mathrm{~g} / 1$ met een variatie van 0 tot $49 \mathrm{~g} / 1$.

Op basis van de grote variatie van de IgG-inhoud van colostrum berekenden meerdere onderzoekers dat het geven van twee liter biest niet voldoet om FPT bij het kalf te voorkomen. Drie tot vier liter biest echter verschaft in het merendeel van de gevallen wel de noodzakelijke minimumgrens van $100 \mathrm{~g} \mathrm{IgG}$ (Besser et al., 1991; Chigerwe et al., 2008).

Als het over een voldoende opname van IgGs door het kalf gaat, dient er ook vermeld te worden dat er in de literatuur voldoende bewijs voorhanden is dat kalveren die bij de moederkoe gelaten worden om biest te zuigen, significant meer kans hebben op FPT (Logan et al., 1981; Besser et al., 1991; Trotz-Williams et al., 2008; Beam et al., 2009). De reden hiervoor is dat kalveren die de vrijheid hebben om te zuigen bij hun moederdier, meestal niet genoeg volume biest opnemen of dat de kalveren pas laat na de geboorte opstaan om te zuigen.

\section{Efficiëntie van absorptie}

\section{Tijdstip van de eerste biestbeurt}

De efficiëntie waarmee antistoffen opgenomen worden in de bloedbaan van het kalf, daalt met de leeftijd van het kalf. Gemiddeld genomen worden deze antistoffen enkel gedurende de eerste 24-36 uur na de geboorte opgenomen. In deze periode heeft de neonatale enterocyt de unieke capaciteit om op een niet-selectieve manier eiwitmacromoleculen op te nemen (Bush et al., 1980; Weaver et al., 2000). Na deze periode 'sluit' de darm zich als het ware voor deze antistoffen. Dit wordt aangeduid met de term "gut closure" (Michanek et al., 1989). De meest efficiënte absorptie is mogelijk in de eerste 4-6 uur na de geboorte van het kalf. Na 12 uur ziet men al een sterke daling van deze efficiëntie (Weaver et al., 2000; Godden, 2008; Beam et al., 2009).

\section{Bacteriologische kwaliteit}

Voor een efficiënte absorptie speelt ook de bacteriologische kwaliteit van de biest een rol. Hoe hoger het gehalte aan bacteriën in de biest, hoe lager de efficiëntie van de absorptie van colostrale antistoffen doorheen de darmwand naar het bloed van het kalf (James et al., 1981; McGuirk and Collins, 2004; Johnson et al., 2007). Dit komt omdat de antistoffen in de biest aan de bacteriën binden en hierdoor niet meer beschikbaar zijn voor absorptie.

\section{Algemene toestand van het kalf}

Ook de algemene toestand van het pasgeboren kalf heeft een invloed op de efficiëntie van de absorptie. Verschillende studies tonen aan dat kalveren die lijden aan metabole acidose, de toegediende antistoffen minder efficiënt opnemen (Jacobsen et al., 2002). In de literatuur bestaat heel wat discussie omtrent dit fenomeen, aangezien volgens sommigen dit verschil enkel te wijten is aan het feit dat kalveren met metabole acidose minder (snel) biest opnemen (Weaver et al., 2000). Anderen gaan ervan uit dat bij acidotische kalveren de "gut closure" wordt uitgesteld tot wel 40 uur 
na de geboorte, hetgeen compenseert voor de lagere opname onmiddellijk na de geboorte (Tyler et al., 1991).

\section{Toevoeging van selenium aan de biest}

Volgens sommigen zou de toevoeging van selenium aan de biest een positieve invloed hebben op de efficiëntie van absorptie. Kamada et al. (2007) zagen bij de toevoeging van 1 en 3 ppm selenium aan de biest een IgG-stijging van respectievelijk 20 en $42 \%$ in het plasma van de onderzochte kalveren. Het zou om een direct effect op het darmepitheel gaan.

\section{Nabijheid van het moederdier}

Volgens een oudere studie zou in het bijzijn van het moederdier de opname van antistoffen naar de bloedbaan van het kalf efficiënter gebeuren (Stott et al., 1979). Het kalf bij de koe laten, geeft echter ook meer kans op besmetting van het kalf door de koe.

\section{Manier van colostrumtoediening}

Wat het verschil tussen biest geven met de speenfles of toediening via een slokdarmsonde betreft, komt de speenfles er het beste uit mits beperkte volumes gegeven worden. Godden et al. (2009) stelden vast dat bij het geven van 1,5 1 biestvervanger, de efficiëntie van absorptie hoger was bij het toedienen met een speenfles dan bij het toedienen met een slokdarmsonde. Dit verschil viel echter weg bij het geven van drie liter biestvervanger. Volgens de auteurs dient de verklaring van deze waarneming gezocht te worden in het feit dat er bij de toediening van drie liter biest met de speenfles ook een overloop is naar de pens en/of een snellere doorstroom doorheen het gastro-intestinaal kanaal. Dit is niet het geval bij het geven van volumes van maximum 1,5 liter (de lebmaag van een pasgeboren kalf is niet groter).

De auteurs van het onderhavig artikel zijn van mening dat toediening met de speenfles de voorkeur geniet, maar dat het toedienen van colostrum met de slokdarmsonde zeker een afdoend alternatief is bij kalveren die om welke reden dan ook niet willen zuigen na de kalving. Wanneer dit op een correcte en hygiënische manier gebeurt, vormt dit op geen enkel vlak een risico voor het kalf. Het belangrijkste is dat er goed gecontroleerd wordt of de sonde zich wel degelijk in de slokdarm bevindt en niet in de trachea. Ook na het opgieten moet er opgelet worden dat er geen biest meer in de sonde zit die in de trachea/longen kan lopen bij het terugtrekken van de sonde. Biest opgieten in de longen betekent voor de meeste kalveren immers het einde.

\section{BELANG VAN COLOSTRALE LEUKOCYTEN}

Het wetenschappelijk onderzoek naar de passieve immuniteit bij jonge kalveren heeft zich de voorbije jaren voornamelijk gefocust op de transfer van colostrale antistoffen. Echter, de laatste tijd krijgen ook an- dere humorale en cellulaire componenten van de immuniteit meer en meer aandacht. Biest bevat net zoals bloed neutrofielen, lymfocyten en macrofagen. Dat deze cellen ook overgaan naar de circulatie van het neonatale kalf werd reeds eerder bewezen (Liebler-Tenorio et al., 2002). Naast het bewijs van opname werden ook verscheidene studies uitgevoerd betreffende de invloed van deze colostrale leukocyten op het neonatale kalf. Riedel-Caspari et al. (1993) vonden dat kalveren die colostrale leukocyten (CLs) krijgen en nadien geïnfecteerd worden met Escherichia coli, minder bacteriën uitscheiden in de mest dan kalveren die geen CLs krijgen. Ook werd in diverse andere studies aangetoond dat CLs zorgen voor een verhoogde lymfocytaire respons tegen niet-specifieke mitogenen, een verhoogde fagocytose capaciteit en dat ze humorale responsen stimuleren (Riedel-Caspari en Schmidt, 1991ab-c). Verder onderzoek is nodig om de precieze praktische invloed van deze cellen na te gaan. Het feit dat de immuuncellen aanwezig in biest een bijdrage leveren tot de immuniteitsopbouw van het pasgeboren kalf, is een extra reden om verse biest te verkiezen boven diepvriesbiest. Dit is vooral van belang in het kader van de preventie van infectieuze ziekten waarbij vooral de cellulaire afweer een belangrijke rol speelt, zoals het geval is bij Cryptosporidium parvum.

\section{HOE KAN "FAILURE OF PASSIVE TRANSFER" GETEST WORDEN?}

Het colostrummanagement op een rundveebedrijf kan eenvoudig getest worden door van een aantal kalveren tussen 2-7 dagen na de geboorte een serumstaal te nemen. Dit bloedstaal kan op verschillende manieren getest worden om te zien of de kalveren voldoende antistoffen hebben in hun bloedbaan. Voor het onmiddellijk meten van de serum IgG-concentratie bestaan er onder meer de RID, de turbidimetrische immuno-assay (TIA) en de ELISA-test. Indirect kan de IgG-inhoud van serum gemeten worden met onder andere de refractometer, de natriumsulfiet- en de zinksulfaatturbiditeitstest en door het meten van de serum-gamma-glutamyltransferase (GGT) activiteit. De meeste methoden vereisen een laboratorium en getraind personeel, maar de refractometer is een voorbeeld van een test die ook gemakkelijk door de dierenarts zelf kan uitgevoerd worden. Naast de refractometer is enkel nog een eenvoudige centrifuge nodig omdat er wordt gewerkt met serum en/of plasma. Zoals reeds aangehaald bij het bepalen van de biestkwaliteit, meet de refractometer hoeveel licht afgebogen wordt, hetgeen overeenkomt met het gehalte aan vaste stoffen in het serum. Aangezien eiwitten behoren tot de vaste stoffen en antistoffen eiwitten zijn, bestaat er een verband tussen de refractieindex en de IgG-inhoud van het serum. De drempel van $5,2 \mathrm{~g} / \mathrm{dl}$ komt overeen met een IgG-inhoud van $10 \mathrm{~g} / 1$ (met een sensitiviteit van 0,89-0,93 en een specificiteit van 0,80-0,84) (Calloway et al., 2002). Aangezien bij zieke kalveren dehydratie kan optreden of een stijging van de acute-fase-proteïnen kan zorgen voor een stij- 
ging van het eiwitgehalte van het serum, is het voor een screening van het colostrummanagement uiteraard aan te raden bloed te nemen van klinisch gezonde kalveren (Tyler et al., 1999b).

\section{BIESTSUPPLEMENTEN EN BIESTVERVANGERS}

Artificieel colostrum kan om verschillende redenen ingezet worden. Naast het feit dat er soms geen biest voorhanden is of dat de biest van slechte kwaliteit is, zouden deze biestvervangers een middel zijn om ziekten die kunnen overgedragen worden via de biest, zoals paratuberculose, preventief aan te pakken. Artificieel colostrum is echter weinig specifiek en bevat meestal geen antistoffen tegen de bedrijfseigen kiemen (hetzelfde probleem geldt voor bedrijven die biest afkomstig van andere bedrijven gebruiken). Bovendien ligt ook de efficiëntie van absorptie lager voor deze artificiële Igs. Naast deze belangrijke nadelen, is biest zoals hierboven reeds vermeld, ook meer dan alleen antistoffen. Er zitten onder andere ook witte bloedcellen, groeifactoren en niet-specifieke antibacteriële factoren in. Al deze componenten worden niet in biestvervangers en -supplementen gevonden.

\section{DE RELATIE TUSSEN BIEST EN BOVIENE NEO- NATALE PANCYTOPENIE}

Sinds 2008 wordt er in meerdere Europese landen, waaronder ook België, een nieuw syndroom vastgesteld dat zich klinisch uit door het optreden van spontane bloedingen bij neonatale kalveren. De aandoening wordt officieel boviene neonatale pancytopenie (BNP) genoemd. Uit de eerste onderzoeksresultaten blijkt dat BNP wordt overgedragen via het colostrum (Bridger et al., 2011) van koeien die gevaccineerd zijn met één bepaald vaccin tegen het boviene virale diarreevirus (BVDV) (Pardon et al, 2010). Aangezien het ziektebeeld nog maar bij een beperkt aantal kalveren die dergelijke biest hebben gekregen, is opgetreden, veronderstelt men dat er naast het vaccin nog andere uitlokkende factoren dienen aanwezig te zijn opdat het syndroom zich klinisch zou veruiterlijken. Er wordt verondersteld dat dit genetisch gebonden factoren zijn (Deutskens et al., 2011).

De Faculteit Diergeneeskunde van de Universiteit Gent heeft meegewerkt aan een internationaal epidemiologisch onderzoek naar de oorzaken van deze ziekte (Pfeiffer et al., 2012). Op basis van een uitgebreide enquête werd interessante informatie ingewonnen omtrent het biestmanagement op de 239 in het onderzoek opgenomen Vlaamse bedrijven. Zo blijkt dat op melkveebedrijven slechts $10 \%$ van de kalveren enkel en alleen biest van de eigen moeder krijgt. Bij vleesvee is dit maar 3\%. Op melkveebedrijven krijgen kalveren meestal wel biest van de eigen moeder, maar bijkomend wordt er ook verse of diepvriesbiest van andere koeien verstrekt. Op vleesveebedrijven wordt er vooral diepvriesbiest bijgegeven (73\%). In 64\% van de gevallen is die afkomstig van een ander bedrijf. Op- vallend is dat slechts één van alle 239 veehouders de naam of het nummer van de koe op het recipiënt aanbrengt. Dit gebrek aan identificatie leidt tot problemen bij de bedrijven waar er BNP is vastgesteld. Het advies hier is namelijk om geen biest meer te geven van een koe die een BNP-kalf heeft voortgebracht. Aangezien men wegens gebrek aan identificatie niet aan deze vraag kan voldoen, dient men in de meeste gevallen de gehele diepvriesvooraad biest te vernietigen. Omdat er op heel wat bedrijven mengbiest wordt gebruikt, weet men in vele gevallen ook niet van welke koe de ziekteverwekkende biest afkomstig is en er dus geen biest mag gegeven worden bij een volgende kalving. Tenslotte blijkt uit de enquête ook dat op $42 \%$ van de vleesveebedrijven de slokdarmsonde gebruikt wordt, maar dan alleen als het kalf niet vlot drinkt. Dit wordt op $28 \%$ van de melkveebedrijven toegepast. Daarnaast gebruiken $3 \%$ van de vleesveehouders en $2 \%$ van de melkveehouders de slokdarmsonde systematisch bij elke biestverstrekking.

\section{REFERENTIES}

Archambault D., Morin G., Elazhary M. (1988). Isolation of bovine colostral lymphocytes - in vitro blastogenic responsiveness to concanavalin A and bovine rotavirus. Annales de Recherches Vétérinaires 19, 169-174.

Arthur G.H. (1996). The development of the conceptus. In: Arthur G.H., Nokes D.E., Pearson H., Parkinson T.J., (editors). Pregnancy and Parturition in Veterinary Reproduction and Obstetrics, 7th ed., PA:WB Saunders, Philadelphia, p.51-109.

Baumrucker C.R., Burkett A.M., Magliaro-Macrina A.L., Dechow C.D. (2010). Colostrogenesis: Mass transfer of immunoglobulin G1 into colostrum. Journal of Dairy Science 93, 3031-3038.

Beam A.L., Lombard J.E., Kopral C.A., Garber L.P., Winter A.L., Hicks J.A., Schlater J.L. (2009). Prevalence of failure of passive transfer of immunity in newborn heifer calves and associated management practices on US dairy operations. Journal of Dairy Science 92, p.3973-3980.

Besser T.E., Gay C.C., Pritchett B.S. (1991). Comparison of three methods of feeding colostrum to dairy calves. Journal of the American Veterinary Medical Association 198, 419- 422.

Bush L.J., Stanley T.E. (1980). Absorption of colostral immunoglobulins in newborn calves. Journal of Dairy Science 63, 672-680.

Butler J.E. (1974). Immunoglobulins of the mammary secretions. In: Larson B.L., Smith V.R. (editors). Lactation: a comprehensive Treatise, Academic Press, New York, p. 217-255.

Calloway C.D., Tyler J.W., Tessman R.K., Hostetler D., Holle J. (2002). Comparison of refractometers and test endpoints in the measurement of serum protein concentration to assess passive transfer status in calves. Journal of the American Veterinary Medical Association 221, 1605-1608.

Chase C.L., Hurley D.J., Reber A.J. (2008). Neonatal Immune Development in the Calf and Its Impact on Vaccine Response. Veterinary Clinics of North America: Food Animal Production 24, 87-104.

Chigerwe M., Tyler J.W., Middleton J.R., Spain J.N., Dill 
J.S., Steevens B.J. (2008). Comparison of four methods to assess colostral IgG concentration in dairy cows. Journal of the American Veterinary Medical Association 233, 761-766.

Chigerwe M., Tyler J.W., Schultz L.G., Middleton J.R., Steevens B.J., Spain J.N. (2008). Effect of colostrum administration by use of oroesophageal intubation on serum IgG concentrations in Holstein bull calves. American Journal of Veterinary Research 69, 1158-1163.

Dawes M.E., Tyler J.W., Hostetler D., Latritz J., Tessman R. (2002). Evaluation of a commercially available immunoassay for assessing adequacy of passive transfer in calves. Journal of the American Veterinary Medical Association 220, 791-793.

Delaquis A.M., Block E. (1995). Dietary cation-anion difference, acid-base status, mineral metabolism, renal function, and milk production of lactating cows. Journal of Dairy Science 78, 2259-2284.

Deutskens F., Lamp B., Riedel C.M., Wentz E., Lochnit G., Doll K., Thiel H.J., Rumenapf T. (2011). Vaccine-induced antibodies linked to bovine neonatal pancytopenia (BNP) recognize cattle major histocompatibility complex class I (MHC I). Veterinary Research 42, 97.

Fleenor W.A., Scott G.H. (1980). Hydrometer Test for estimation of immunoglobulin concentration in bovine colostrum. Journal of Dairy Science 63, 973-977.

Foley J.A., Otterby D.E. (1978). Availability, storage, treatment, composition and feeding value of surplus colostrum: a review. Journal of Dairy Science 61, 1033-1060.

Furman-Fratczak K., Rzasa A., Stefaniak T. (2011). The influence of colostral immunoglobulin concentration in heifer calves's serum on their health and growth. Journal of Dairy Science 94, 5536-5543.

Georgiev I.P. (2008). Differences in chemical composition between cow colostrum and milk. Bulgarian Journal of Veterinary Medicine 11, 3-12.

Godden S. (2008). Colostrum management for dairy calves. Veterinary Clinics of North America: Food Animal Production 24, 19-39.

Godden S.M., Haines D.M., Konkol K., Peterson J. (2009). Improving passive transfer of immunoglobulins in calves. II: Interaction between feeding method and volume of colostrum fed. Journal of Dairy Science 92, 1758-1764.

Haines D.M., Godden S.M. (2011). Improving passive transfer of immunoglobulins in calves. III. Effect of artificial mothering. Journal of Dairy Science 94, 1536-1539.

Herr M., Bostedt H., Failing K. (2011). IgG and IgM levels in dairy cows during the periparturient period. Theriogenology 75, 377-385.

Jacobsen H., Sangild P.T., Schmidt M., Holm P., Greve T., Callesen H. (2002). Macromolecule absorption and cortisol secretion in newborn calves derived from in vitro produced embryos. Animal Reproduction Science 70, 1-11.

Johnson J.L., Godden S.M., Molitor T., Ames T., Hagman D. (2007). Effects of Feeding Heat-Treated Colostrum on Passive Transfer of Immune and Nutritional Parameters in Neonatal Dairy Calves. Journal of Dairy Science 90, 5189-5198.

Kamada H., Nonaka I., Ueda Y., Murai M. (2007). Selenium Addition to Colostrum Increases Immunoglobulin G Absorption by Newborn Calves. Journal of Dairy Science 90, 5665-5670.

Kehoe S.I., Jayarao B.M., Heinrichs A.J. (2007). A survey of bovine colostrum compositon and colostrum management practices on pennsylvania dairy farms. Journal of Dairy Science 90, 4108 - 4116.
Kemler R., Mossmann H., Strohmaier U., Kickhöfen B., Hammer D.K. (1975). In vitro studies on the selective binding of IgG from different species to tissue sections of the bovine mammary gland. European Journal of Immunology 5, 603-608.

Klaus G.G.B, Bennet A., Jones E.W. (1969). A quantitative study of the transfer of colostral immunoglobulins to the newborn calf. Immunology 16, 293 - 299.

Kruse V. (1970). Yield of colostrum and immunoglobulin in cattle at first milking after parturition. Animal Production 12, 619-626.

Kuralkar P., Kuralkar S.V. (2010). Nutritional and immunological importance of colostrum fort the new born. Veterinary World 3, 46-47.

Lacetera N., Bernabucci U., Ronchi B., Nardone A. (1996). Effects of selenium and vitamin $\mathrm{E}$ administration during a late stage of pregnancy on colostrum and milk production in dairy cows, and on passive immunity and growth of their offspring. American Journal of Veterinary Research 12, 1776-1780.

Levieux D., Ollier A. (1999). Bovine immunoglobulin G, blactoglobulin, a-lactalbumin and serum albumin in colostrum and milk during the early post partum period. Journal of Dairy Research 66, 421-430.

Logan E.F., Musket B.D., Herron R.J. (1981). Colostrum feeding of dairy calves. Veterinary Record 108, 283-284.

McGuirk S.M., Collins M. (2004). Managing the production, storage, and delivery of colostrum. Veterinary Clinics of North America: Food Animal Production 20, 593-603.

McMartin S. (2006). Heat treatment of bovine colostrum. I: Effects of temperature on viscosity and immunoglobulin G level. Journal of Dairy Science 89, 2110-2118.

Mechor G.D., Grohn Y.T., McDowell L.R., Van Saun R.J. (1992). Specific gravity of bovine colostrum immunoglobulins as affected by temperature and colostrum components. Journal of Dairy Science 75, 3131-3135.

Michanek P., Ventorp M., Weström B. (1989). Intestinal transmission of macromolecules in newborn dairy calves of different ages at first feeding. Research in Veterinary Science 46, 375-379.

Moore M., Tyler J.M., Chigerwe M., Dawes M.E., Middleton J.R. (2005). Effect of delayed colostrum collection on colostral IgG concentration in dairy cows. Journal of the American Veterinary Medical Association 226, 13751377.

Moore D.A., Taylor J., Hartman M.L., Sischo W.M. (2009). Quality assessments of waste milk at a calf ranch. Journal of Dairy Science 92, 3503-3509.

Morin D.E., Constable P.D., Maunsell F.P., McCoy G.C. (2001). Factors associated with colostral specific gravity in dairy cows. Journal of Dairy Science 84, 937-943.

Morin D.E., Nelson V., Reid E.D., Nagy D.W., Dahl G.E., Constable P.D. (2010). Effect of colostral volume, interval between calving and first milking, and photoperiod on colostral IgG concentrations in dairy cows. Journal of the American Veterinary Medical Association 237, 420-428.

Muller L.D., Ellinger D.K. (1981). Colostral immunoglobulin concentrations among breeds of dairy cattle. Journal of Dairy Science 64, 1727-1730.

Nardone A., Lacetera N., Bernabucci U., Ronchi B. (1997). Composition of colostrum from dairy heifers exposed to high air temperatures during late pregnancy and the early postpartum period. Journal of Dairy Science 80, 838-844.

Newby T.J., Stokes C.R., Bourne F.J. (1982). Immunological activities of milk. Veterinary Immunology and Immunopathology 3, 67-94. 
Ohtsuka H. (2010). Effect of parity on lymphocytes in peripheral blood and colostrum of healthy Holstein dairy cows. Canadian Journal of Veterinary Research 74, 130135.

Pardon B., Steukers L., Dierick J., Ducatelle R., Saey V., Maes S. Vercauteren G., De Clercq K., Callens J., De Bleecker K., Deprez P. (2010). Haemorrhagic diathesis in neonatal calves: an emerging syndrome in Europe. Transboundary and Emerging Diseases 57, 135-146.

Pavlata L., Prasek J., Filipek J., Pechova A. (2004). Influence of parenteral administration of selenium and vitamin $\mathrm{E}$ during pregnancy on selected metabolic parameters and colostrum quality in dairy cows at parturition. Veterinárni medicina 49, 149-155.

Pfeiffer D.U., Sauter-Louis C., Henning J., Stoll A., Nielen M., Schouten M., Van Schaik G., Smolenaars A., Fourichon C., Guatteo R., Madouasse A., Deprez P., De Vliegher S., Laureyns J., Jones B., Booth R., Cardwell J. (2012). A multi-country epidemiological investigation of bovine neonatal pancytopenia (BNP). In: Proceedings of the ECVPH Annual Scientific Conference, Maastricht, 23-24 August, p 157.

Pritchett L.C., Gay C.C., Besser T.E., Hancock T.C. (1991). Management and production factors influencing immunoglobulin G1 concentration in colostrum from holstein cows. Journal of Dairy Science 74, 2336-2341.

Pritchett L.C., Gay C.C., Hancock D.D., Besser T.E. (1994). Evaluation of the hydrometer for testing Immunoglobulin G1 concentrations in Holstein colostrum. Journal of Dairy Science 77, 1761-1767.

Quigley J.D., Martin K.R., Dowlen H.H., Wallis L.B., Lamar K. (1994). Immunoglobulin concentration, specific gravity, and nitrogen fractions of colostrum from Jersey Cattle. Journal of Dairy Science 77, 264-269.

Quigley J.D., Drewry J.J. (1998). Nutrient and immunity transfer from cow to calf pre- and postcalving. Journal of Dairy Science 81, 2779-2790.

Riedel-Caspari G., Schmidt F.W. (1991a) The influence of colostral leukocytes on the immune system of the neonatal calf. I. Effects on lymphocytes responses. Deutsche Tierärtzliche Wochenschrift 98, 102-107.

Riedel-Caspari G., Schmidt F.W. (1991b) The influence of colostral leukocytes on the immune system of the neonatal calf. II. Effects on passive and active immunization. Deutsche tierärtzliche Wochenschrift 98, 190-194.

Riedel-Caspari G., Schmidt F.W. (1991c) The influence of colostral leukocytes on the immune system of the neonatal calf. III. Effects on phagocytosis. Deutsche Tierärtzliche Wochenschrift 98, 330-334.

Riedel-Caspari G. (1993). The influence of colostral leukocytes on the course of an experimental Escherichia coli infection and serum antibodies in neonatal calves. Veterinary Immunology and Immunopathology 35, 275-288.

Robison J.D., Stott G.H., Denise S.K. (1988). Effects of passive immunity on growth and survival in the dairy heifer. Journal of Dairy Science 71, 1283-1287.

Stabel J.R., Hurd S., Calvente L., Rosenbusch R.F. (2004). Destruction of Mycobaterium paratuberculosis, Salmonella spp., and Mycoplasma spp. in raw milk by a commercial on-farm high-temperature, short-time pasteurizer. Journal of Dairy Science 87, 2177-2183.

Stott G.H., Marx D.B., Menefee B.E., Nightengale G.T. (1979). Colostral immunoglobulin transfer in calves. IV. Effect of Suckling. Journal of Dairy Science 62, 19081913.
Trotz-Williams L.A., Leslie K.E., Peregrine A.S. (2008). Passive immunity in ontario dairy calves and investigation of its association with calf management practices. Journal of Dairy Science 91, 3840-3849.

Tucker W.B., Hogue J.F., Waterman D.F., Swenson T.S., Xin Z., Hemken R.W., Jackson J.A., Adams G.D., Spicer L.J. (1991). Role of sulfur in the dietary cation-anion balance equation for lactating dairy cattle. Journal of Animal Science 69, 1205.

Tyler H., Ramsey H. (1991). Hypoxia in neonatal calves: effect on intestinal transport of immunoglobulins. Journal of Dairy Science 74, 1953-1956.

Tyler J.W., Hancock D.D., Parish S.M., Rea D.E., Besser T.E., Sanders S.G., Wilson L.K. (1996). Evaluation of 3 assays for failure of passive transfer in calves. Journal of Veterinary Internal Medicine 10, 304-307.

Tyler J.W., Hancock D.D., Wiksie S.E., Holler S.L., Gay J.M., Gay C.C. (1998). Use of serum protein concentration to predict mortality in mixed-Source dairy replacement heifers. Journal of Veterinary Internal Medicine 12, 7983.

Tyler J.W., Steevens B.J., Hostetler D.E., Holle J.M., Denbigh J.L. Jr. (1999a). Colostral immunoglobulin concentrations in Holstein and Guernsey cows. American Journal of Veterinary Research 60, 1136-1139.

Tyler J.W., Parish S.M., Besser T.E., Van Metre D.C., Barrington G.M., Middleton J.R. (1999b). Detection of low serum immunoglobulin concentrations in clinically Ill calves. Journal of Veterinary Internal Medicine 13, 4043.

Tyler J.W., Hancock D.D., Thorne J.G., Gay C.C., Gay J.M. $(1999 \mathrm{c})$. Partitioning the mortality risk associated with inadequate passive transfer of colostral immunoglobulins in dairy calves. Journal of Veterinary Internal Medicine 13, 335-337.

Vermorel M., Dardillat C., Vernet J., Saido, Demigne C. (1983). Energy metabolism and thermoregulation in the newborn calf. Annales de Recherches Vétérinaires 14, 382-389.

Waldner C.L., Rosengren L.B. (2009). Factors associated with serum immunoglobulin levels in beef calves from Alberta and Saskatchewan and association between passive transfer and health outcomes. Canadian Veterinary Journal 50, 275-281. 